\title{
Transport
}

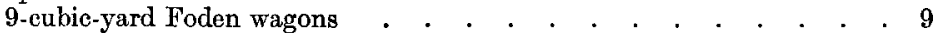

Tipping lorries up to 5-ton capacity . . . . . . . . . . . . . . . 7

Muirhill dumper . . . . . . . . . . . . . . . . . . . I

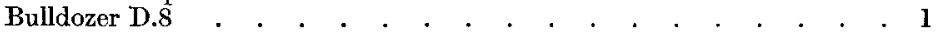

Bulldozer D.4

Concreting plant

Blaw Knox 1-cubic-yard batcher . . . . . . . . . . . . 1

Blaw Knox Junior weigh-batchers . . . . . . . . . . . . 2

Piling plant

70 feet raking pile frame . . . . . . . . . . . . . . 1

40 feet ," with i5-foot extension . . . . . . . 1

McKiernan Terry D.A. hammer No. 7 . . . . . . . . . . . . . . 1

Mckiernan Terry ", "No. 9 B.3 . . . . . . . . . . . 1

McKiernan Terry " hammers No. 10 B.3 . . . . . . . . . . 2

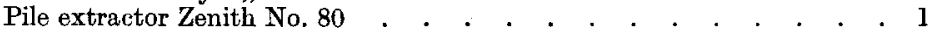

Pumps

12-inch Centrifugal electric (for dewatering)

10-inch " $"$ Diesel (for dewatering)

6-inch " $"$ electric

5-inch ",

,

Miscellaneous

Welding transformers . . . . . . . . . . . . . . . 3

Welding generator . . . . . . . . . . . . . . . . 1

Air-compressor : 300 cubic feet per minute . . . . . . . . . 1

10-ton Diesel roller . . . . . . . . . . . . . . . . . . . . . 1

Appleyard boring rig . . . . . . . . . . . . . . . . 1

\section{APPENDIX V}

SUB-CONTRACTORS

Principal sub-contractors and others employed on the work were :-

Entrance gate and filling valve . . Sir William Arrol \& Co. Ltd.

Pumping equipment . . . . Drysdale \& Co. Ltd.

Sheet-piling . . . . . . British Steel Piling Co.

Do. (arch dam) . . . United Steel Co. Ltd.

Cranes (dockside) . . . . . . Stothert \& Pitt, Ltd.

Capstans . . . . . . . Clarke, Chapman \& Co. Ltd.

Platers'shed steelwork . . . . Cargo Fleet Iron Co. Ltd.

Keel blocks . . . . . . . Pease and Partners.

Quoin and sill stones . . . . . The Empire Stone Co. Ltd.

In-situ piling . . . . . . . Holmpress Piles, Ltd.

Lift and machinery . . . . . Keighley Lifts, Ltd.

Site investigation . . . . . Soil Mechanics, Ltd.

Services . . . . . . . Smith's Dock Co. Ltd.

\section{Discussion}

The Chairman said that the Author's slides had given some idea of the conditions on the site and the problems met with in demolishing existing works although repairs to ships had still to go on. The design had many 
interesting features, and the Author was to be congratulated on trying out new methods to cheapen the cost of docks. The Chairman had recently visited the Suez Canal, and noted from the Paper that the Author's dock had been designed for super-tankers, the dock having been given a total length of 709 feet. He had had the opportunity of going through the Suez Canal on a super-tanker of 38,000 tons d.w. and 708 feet long, so that it would have just got into the dock and would have had 9 inches clearance on either side of the entrance. It was known, however, that tankers were being built of 45,000 tons. He hoped that the Author would be able to throw light on why the dimensions adopted for the dock had been chosen.

It was a difficult problem nowadays to decide just how much money should be sunk in such a structure. In the case of the Suez Canal a great deal of work was necessary to make the Canal wide and deep enough to take those super-tankers, the owners of which were not interested in paying the dues for work for which they alone really created the need. Would that new dry dock now, several years after it had been conceived, meet the requirements, or would the owners in the present circumstances have been prepared to face the heavy cost of excavating still farther into the hillside to make the dock a few feet longer?

Lt-Col. T. Eustace Smith observed that the site on which the new dry dock had been built had been considered many times in the past, but had always been regarded as impossible because of the very large cost of excavation. It was interesting that modern methods of excavation had made the site available, and, as things had turned out, it had ended up by being an excellent site. It had a good angle to the river, which gave plenty of room for the manceuvring of ships, whilst the high bonks round the dock afforded considerable protection from bad weather, wind, and rain. It also had the advantage during construction that virtually, except for the old pontoon which would have had to be removed in any case, it was outside the yard of Smith's Dock Co. Ltd, so that the work of construction had not interfered with the work going on in the yard.

The Chairman had asked why the size adopted for the dock had been chosen. Smith's Dock Co. Ltd had been aware that bigger tankers were going to be built, or were being built, but they had to bear in mind the size of their other docks, where they could dock the T2 tankers but not modern tankers of 18,000 tons. If a dock had been built which would take a 45,000 - or 50,000-ton tanker, then when docking a ship of 18,000 tons an enormous amount of pumping out would have been necessary. They did not believe that the very large tankers would come to the north-east coast in any numbers; the 32,000-ton ship was the one which they thought would come to Britain. The 45,000-ton vessel which the Chairman had seen had perhaps been going to America, not to Britain. That represented their view at the moment. There was no reason why they should not progress if it became desirable to do so, but for the time being it was felt that they 


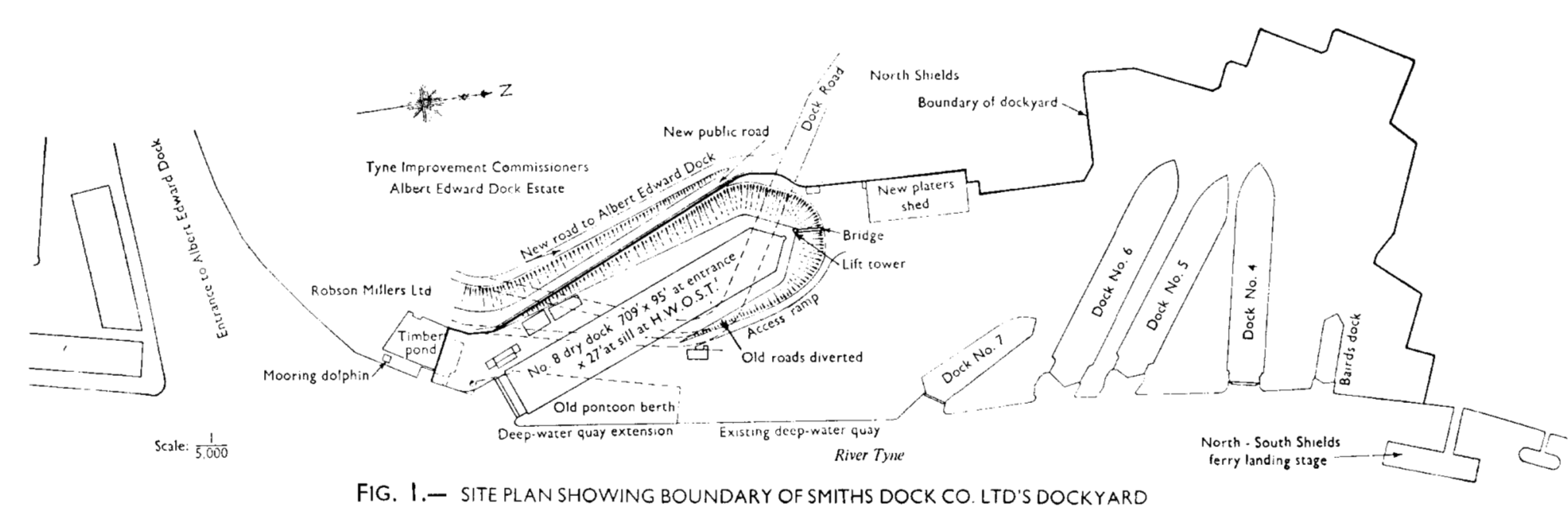

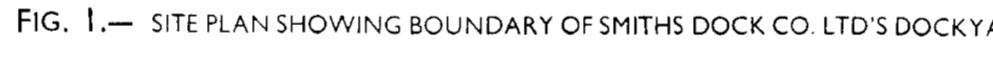

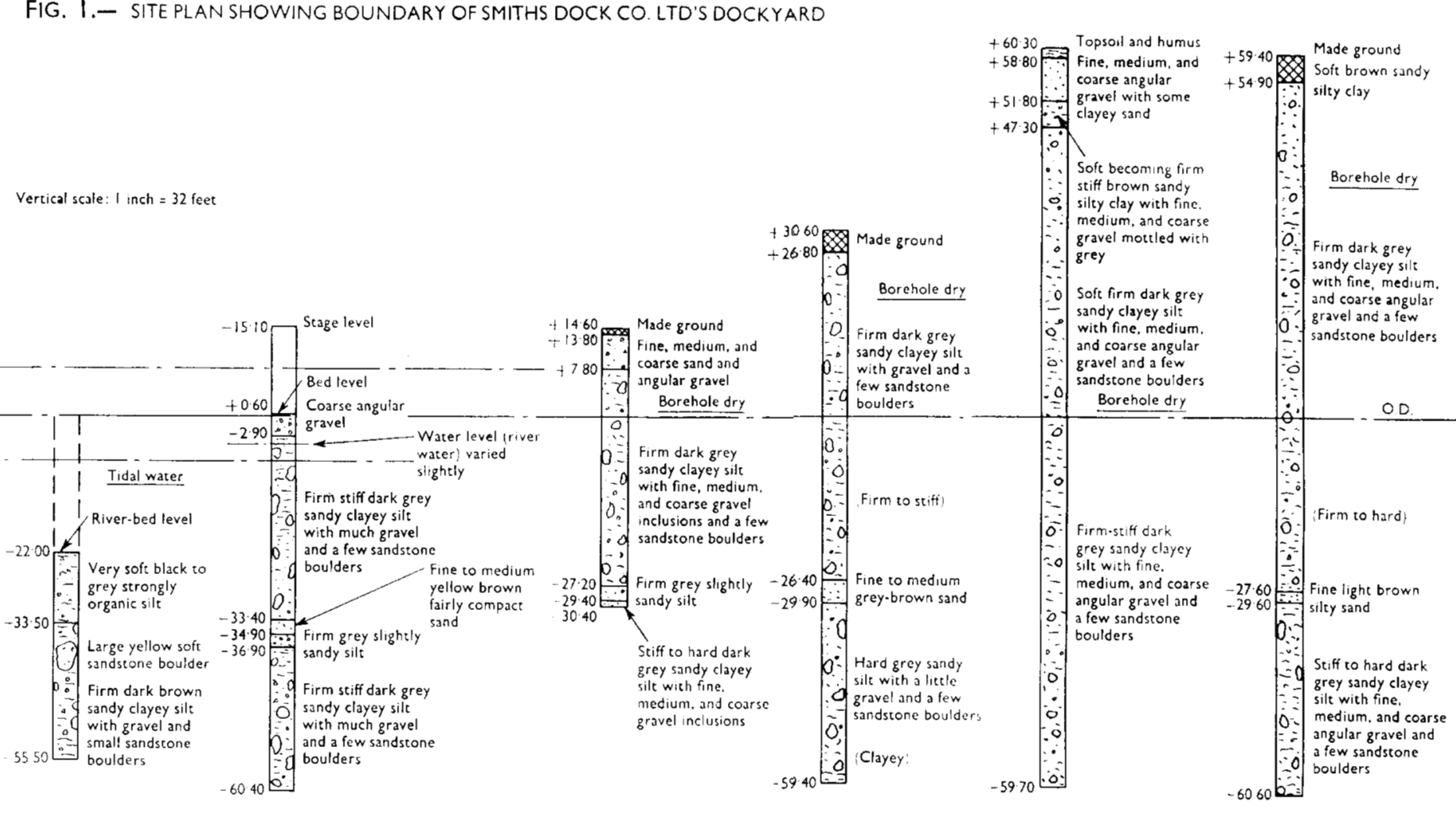

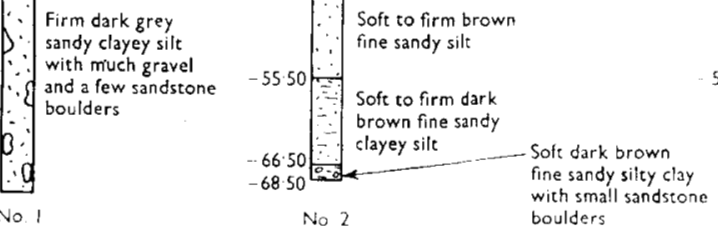

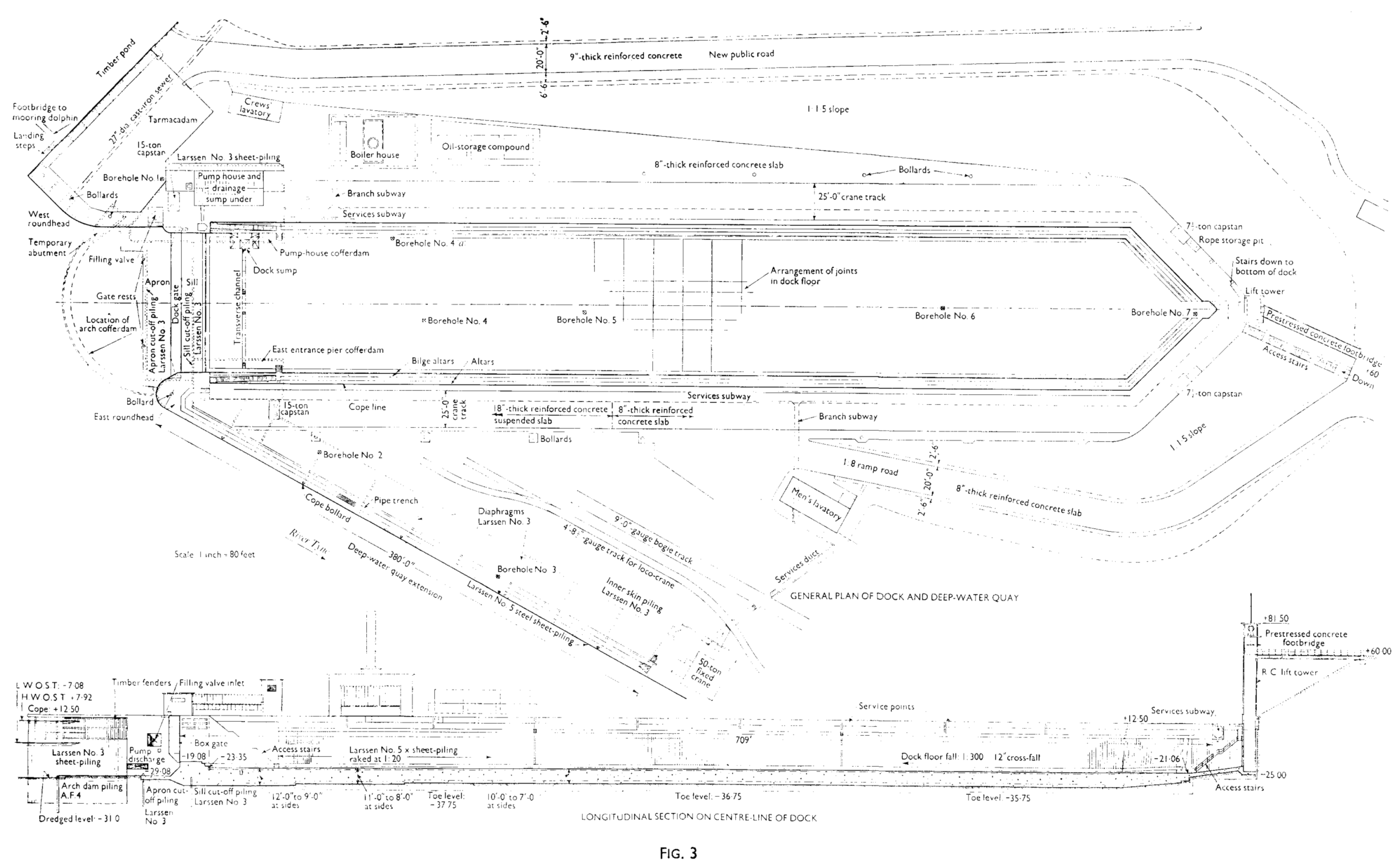




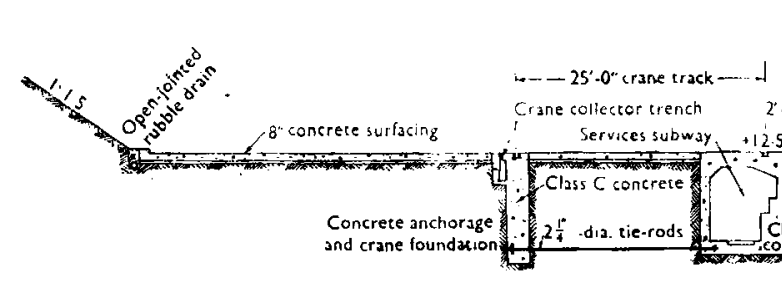

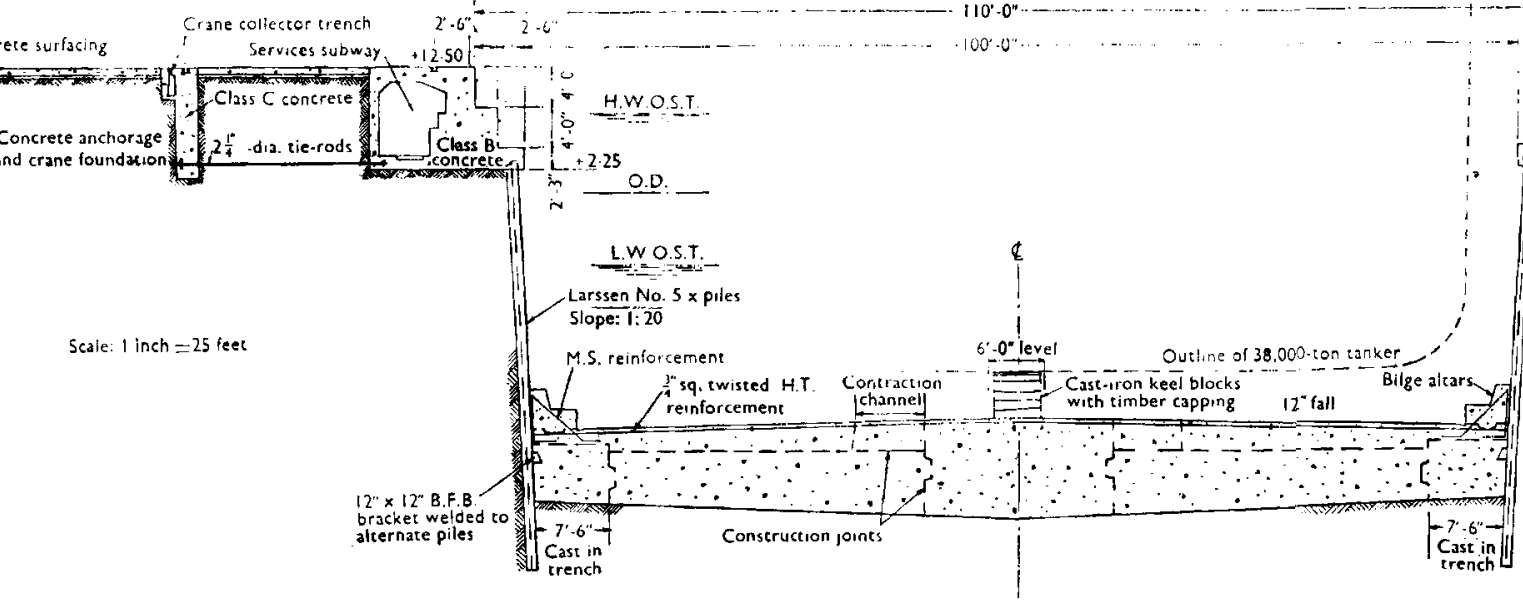

FiG. 4.-TYPICAL CROSS-SECTION OF DOCK
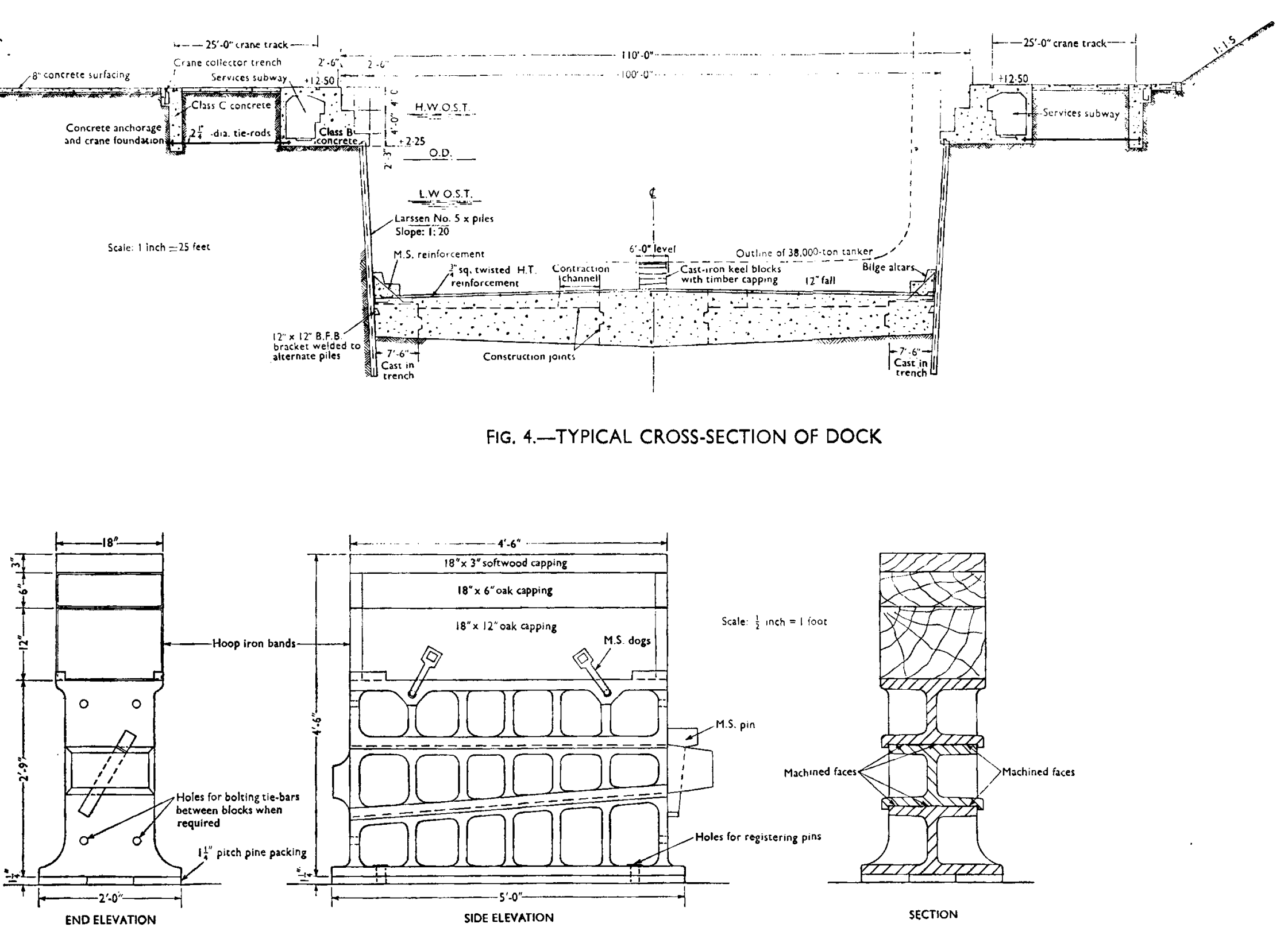

FiG. 9.-DETALLS OF KEEL BLOCKS
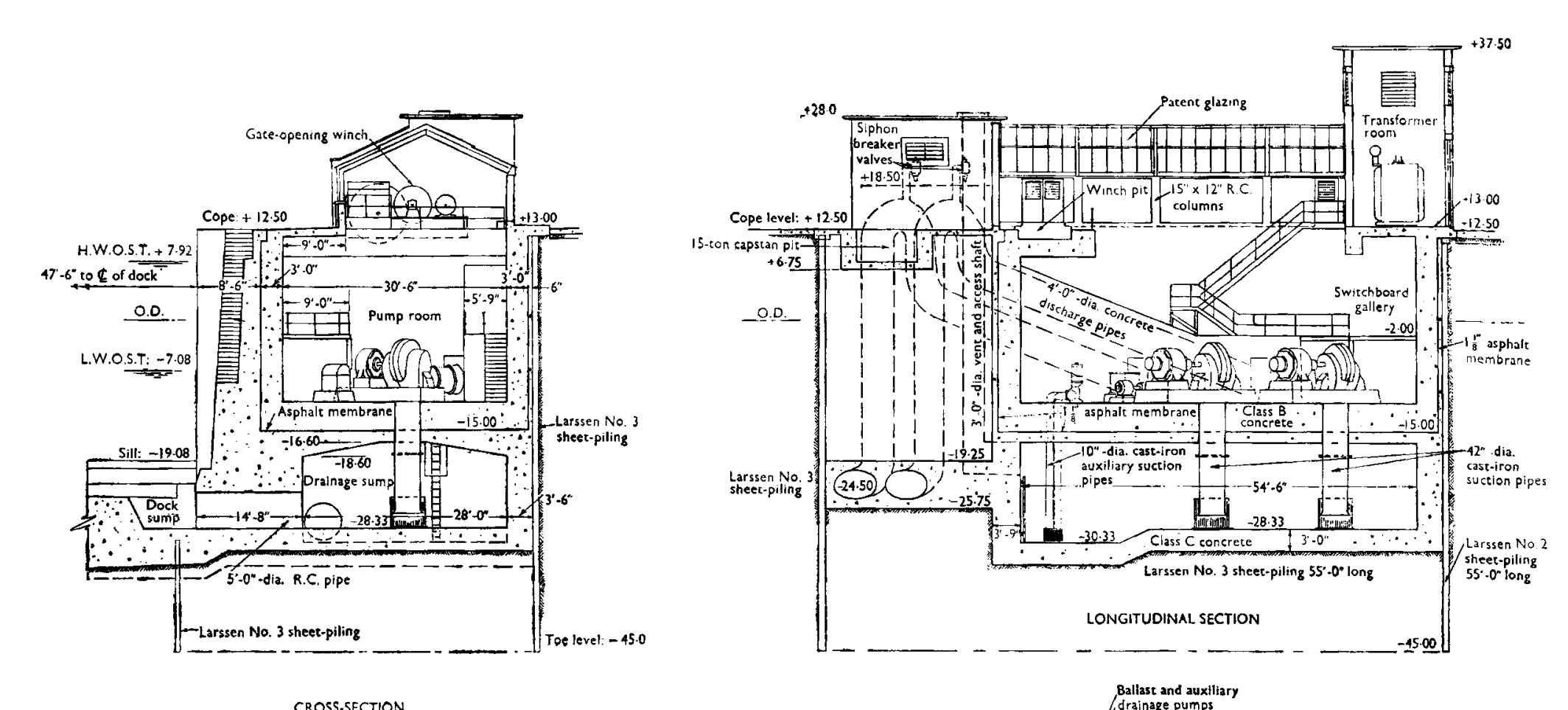

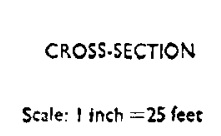

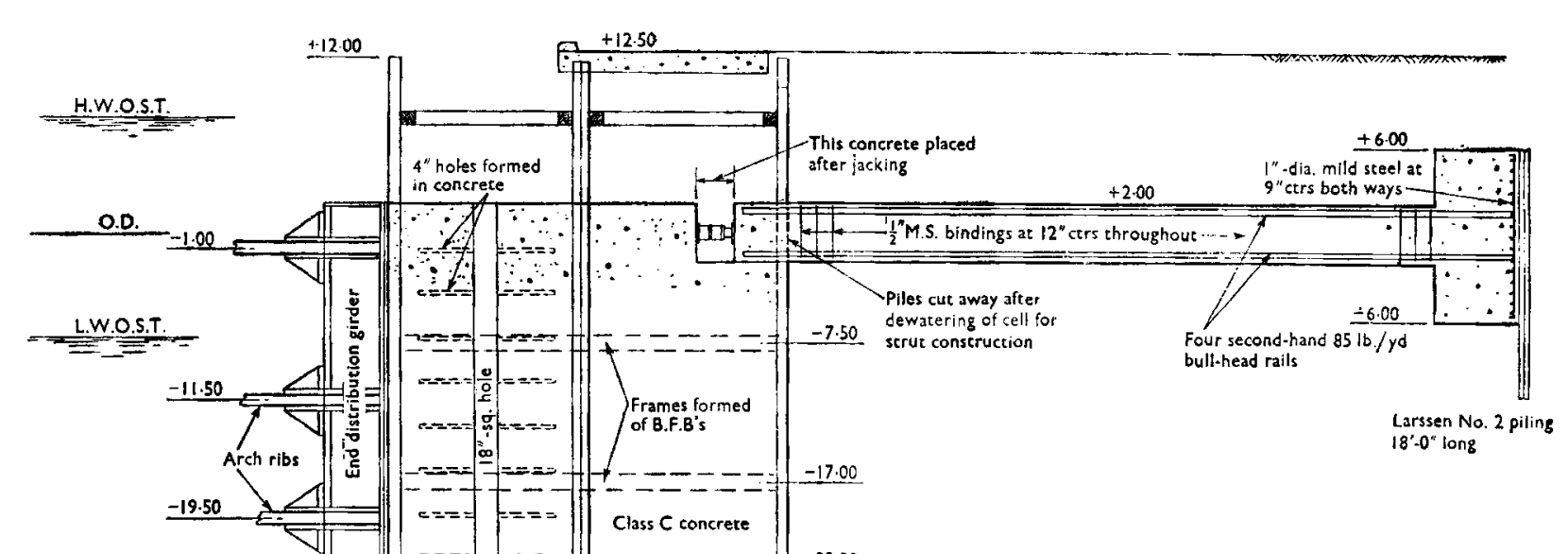

$=0.200=-2000$

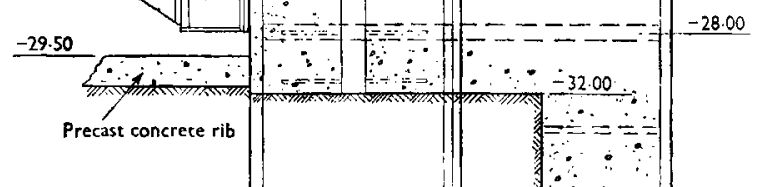

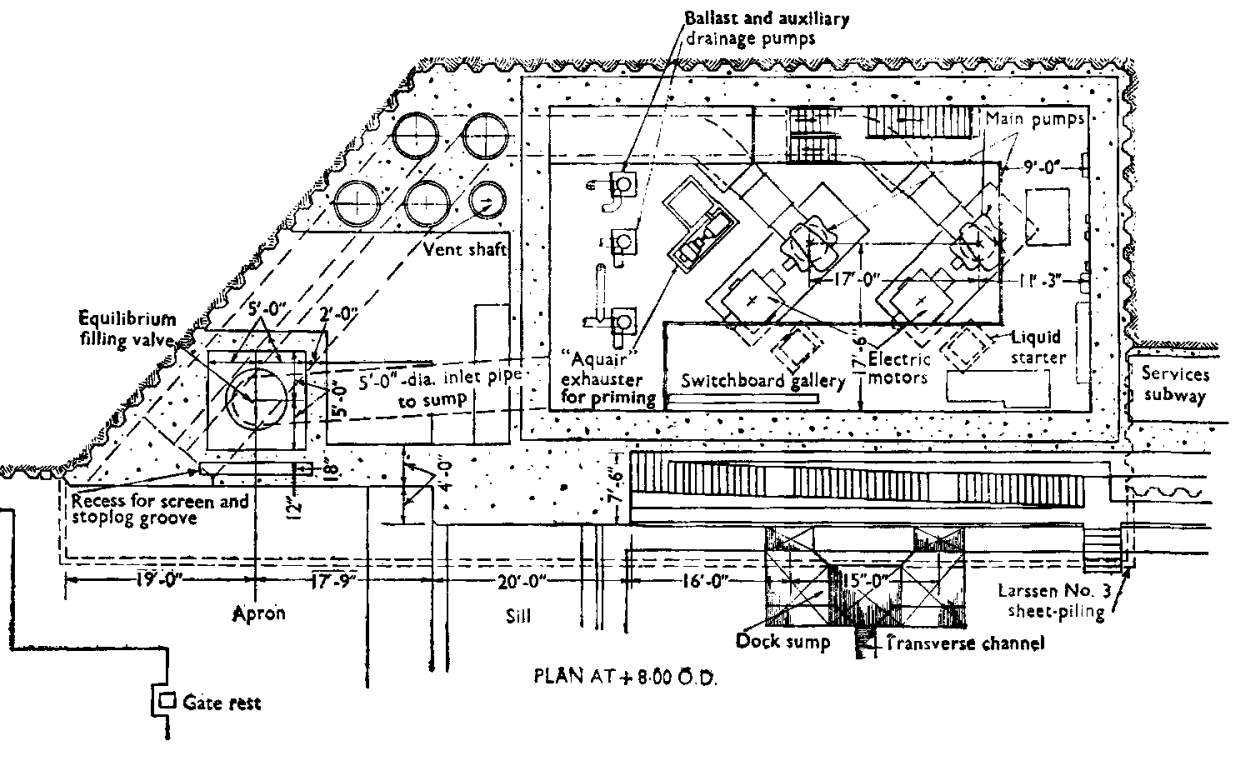

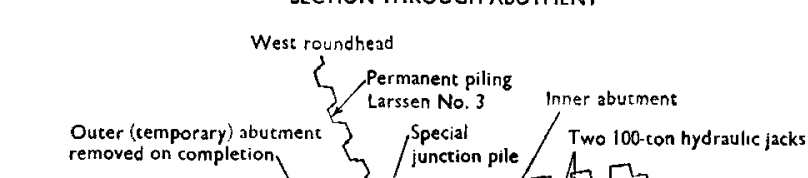

$+1$

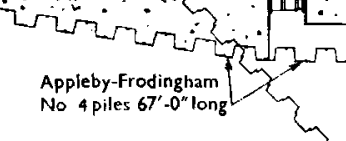

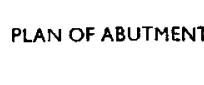

FiG. 10.-ARRANGEMENT OF TEMPORARY ABUTMENT FOR ARCH COFERDAM 
had gone far enough if they provided for ships of 32,000 tons, and if there were some of 38,000 tons it would be possible to get them in.

It had been unfortunate that there had been difficulty in driving the piles, because that had undoubtedly deprived them of the advantage which would otherwise have been gained by the cheaper construction adopted and had also lengthened the time taken for the completion of the job. Colonel Smith did not think that the amount of whinstone boulders on the site, or the effect on the very heavy piles used when they hit those boulders could have been foreseen. He was not certain whether it would have been desirable to have taken more borings or if it would have been possible in that way to have obtained further information on the nature of the ground beforehand, but he was still satisfied that steel sheet-piling in certain circumstances made an extremely good dock side. Even in the actual circumstances, with the difficulty in driving the piles, the cost had not been greater than would have been necessary had normal methods been adopted.

Mr P. W. E. Holloway congratulated the Author on the adoption of steel sheet-piling for permanent dock-wall construction. Although the final cost of the civil engineering work had proved to be considerably greater than had originally been expected, it seemed clear that a capital saving had been achieved by the adoption of that method.

Some of the difficulties encountered during the contract had been very serious. The unexpected presence of so many large whinstone boulders had had a fundamental effect on the progress of the whole job. They had seriously disorganized not only the pile-driving operations but also the other operations which were dependent on them. That, of course, had completely disorganized the work in certain areas. The whole sequence of operations had in many cases been reversed, and a serious increase in cost had been caused, which had been a serious matter to the contractors. They had been fortunate in having clients who had been quick to appreciate the difficulties, and whose assurance of a fair and reasonable settlement at the end of the contract had resulted in immediate encouragement to those responsible to drive ahead with alternative methods with the utmost determination.

Mention had been made of the decision to construct an arch dam across the dock entrance in place of the double-skin gravity dam which had been envisaged at the tendering stage. The design for the arch dam had been included in their tender, and there was no doubt that a saving had been effected as a result; in fact, it was probably true to say that that one factor had enabled them to obtain the contract. An obvious example of that saving was given by the reduced cost of removing the steel sheet-piling from the arch dam as compared with the obviously greater cost of removing two rows of steel sheet-piling with their end sections and the filling contained within them. It was unfortunate, however, that the full benefit of that scheme had been denied to them because of the failure of the 
pump-house cofferdam owing to the sand pockets in the foundations, which prevented the use of the pump-house structure as an abutment to take the thrust of the arch dam.

Mr Holloway apologized for the absence of Mr B. I. Palmer, their Director resident in the North of England, who had unfortunately been unable to attend, and who could have made a valuable contribution to the discussion. He also congratulated the Resident Engineer, Mr Storrar, and the Contractor's Agent, Mr Mitchell, to both of whom much of the credit was due for bringing the job to a successful conclusion.

Mr E. Loewy asked the Author if he could disclose more information about the costs than the overall figure given in the Paper. It might be possible to do so using the "breakdown " method which had been proposed by Mr Wynne Edwards some years ago, on a sort of unit-man-hour basis.

Mr Loewy had made a rough calculation eliminating those elements of the job which were peculiar to the situation, such as the heavy overburden excavation and the pump-house and quay, so as to arrive at a unit cost of the dry dock itself, and he had obtained a figure of about $£ 1,500$ per foot run of length. Would the Author be prepared to give some idea of the cost in money terms, as well as in terms of time, of the difficulties which had been encountered by reason of the presence of the boulders?

With regard to those boulders, Mr Loewy asked what was the Author's reaction now to the fact that he had chosen not to take borings along the lines of the walls, except in one case, but had preferred to take them down the centre-line of the dock only. Another question which might have been put had been answered by the excellent slides which the Author had shown - that was whether the boulders had been disclosed to any extent during the overburden excavation. From a slide of the subway excavation it seemed that a fair number had been disclosed during that excavation.

Turning to smaller points of design detail, Mr Loewy asked for more information about the filling valve. Had its adoption been a matter not only of tradition in the area but also of cost and efficiency, or had it been concerned, in addition, with the question of delivery times for the conventional sluice valve?

No covering had been provided for the collector trench. It would be of interest to know whether the 2-inch gap had proved thoroughly satisfactory for the passage of the pick-up arms on the cranes and whether or not trouble had been experienced with people catching their feet in it, or bars and bolts falling in. Mr Loewy's firm had considered all sorts of fancy devices for covering those slots, and it seemed as though the Author had solved the problem by omitting the covers completely. It was not clear from the Paper, however, how access was obtained to the small trench to install and maintain the wires, etc., because there seemed to be only a thin top slot into which one could not even get one's hand.

Referring to the pump delivery siphon, Mr Loewy mentioned that a 
similar device had been adopted in the cooling-water delivery system of the Brighton B power station.

Had fluid couplings been used or considered as part of the gate-operating transmission system?

With regard to the floor design, had any information been obtained about the actual water pressure under the floor, and had consideration been given to using a vented and drained floor? By that means it might have been possible to use a floor only half as thick as that actually employed, or even less.

Turning to the quay design, Mr Loewy asked why it had been necessary to dewater the area between the quay face and the land. If that had not been necessary, the quay wall could have been built with a single line of piling, which would probably have led to a considerable reduction in cost.

The low concrete strengths specified were very interesting. Had they been specified because of the well-known difficulty of obtaining good aggregates in that area? A similar dock constructed at Sunderland had been described by Ridehalgh, ${ }^{2}$ and a point not brought out in that Paper was that rather higher strengths had been specified, but not in fact generally achieved.

Instead of the semi-trenching system finally adopted in order to get the piles into position, might not it have been possible to put a line of borings along the line of the piling, say at 2 -foot centres, and thereby have reduced the amount of material which had to be displaced by the piles? In the driving of the piles, had the subway structure been in any way disturbed ?

Whatever the conclusion might be about other methods of construction, sheet-piling seemed to be a thoroughly logical material to use for large dry docks, and it was good to see that it had at last been adopted. The difficulties which had been encountered seemed to be a matter of bad luck as much as anything else.

Mr W. Storey Wilson observed that prior to the award of the contract, only eight boreholes had been sunk to prove the ground on what was an extensive site. It was stated in the Paper that "In boreholes Nos 2, 3, and 4 river water was present throughout the boring and the water levels varied with the tide." That should have rung a warning bell, but neither the engineer nor the contractor had paid any heed to it. The trouble really started during the construction of the pump-house cofferdam, and, to quote again from the Paper, "When excavation had almost reached formation level a blow occurred.... This was satisfactorily sealed but another took place very soon afterwards. Further work was stopped while a series of core borings, supplemented by a number of wash borings, was put down. These revealed the presence of a fairly extensive sand pocket

2 Harry Ridehalgh, "The Reconstruction of Greenwell's No. 1 Dry Dock and An. cillary Works at Sunderland." Proc. Instn Civ. Engrs, Pt II, vol, 2, p. 321 (June 1953). 
varying in depth to a maximum of 11 feet. . . This was not revealed by boring No. 1 which appeared to be just on the edge of the pocket." It was unfortunate that that extensive sand pocket, to a depth of 11 feet, had not been disclosed by the borings. The cofferdam had been abandoned and the temporary abutment for the arch dam constructed in order to allow the work to proceed.

That delay, however, had not prevented the contractor from proceeding with the pile-driving working from the head of the dock to the entrance. $\mathrm{Mr}$ Wilson wondered whether the engineer or the contractor had been the greater optimist, the engineer in deciding to have piles driven 40 feet into the tough boulder clay or the contractor in undertaking to do the work and actually putting a price for doing it. It had very soon become apparent that the piles could not be driven into the boulder clay, and it had been suggested that the contractor was not hitting them hard enough. A concentrated effort had been made to drive one pair of piles, and after 27 hours-3 days of solid driving - the head of the pile reached the required level, but excavation revealed that that pile and also the piles adjacent to it not only had declutched but were all over the place. That had been convincing, and it was agreed to trench for the piles and more or less place them rather than drive them into position.

The decision of the contractor to close the entrance by an arch dam having the roundhead backed by the entrance pier as one abutment and the pump-house as the other was sound engineering. When constructed with the temporary abutment the dam had been watertight and stable. Moreover, when the dock had been completed and the gate stepped and tested it had been removed in a matter of days, whereas a gravity-filled dam, which would have been much more expensive, would have taken several months to remove. It had meant that valuable time had been saved.

When the piles forming the arch dam had been driven some of them had met obstructions, and fourteen had refused at from 3 to 10 feet above the projected toe level. It was stated in the Paper that " The contractor did not consider it safe to attempt to dewater under these conditions and decided to form a concrete curtain in the gaps where the toes of the piles were standing high." That had been an important decision which the contractor had had to take. By that time it was known that there were sand pockets in the clay, and if a blow had taken place in the arch dam similar to that which had taken place in the pump-house dam it would have been catastrophic; the whole job would have been completely washed out and it might have been years before it was completed. The contractor had therefore taken that decision, which $\mathrm{Mr}$ Wilson was sure was correct.

There was, however, a lesson to be learnt from the contract. There should have been adequate site investigation before the design was finalized. The borings made should have been sufficient in number to disclose the real nature of the subsoil. It should not have come as a surprise that piles could not be driven and that water-bearing sand areas existed where 
none had been expected. He ventured to suggest that if the knowledge available at the end of the contract had been available before it commenced, and if the consulting engineer had consulted the contractor, the contractor would have proposed that the pump-house and the east roundhead should be sunk as compressed-air caissons, and so provided adequate and secure abutments for the arch dam. If that had been done Mr Wilson believed that the job would have been carried out at less cost and in very much less time. However, presumably they would have to go on in the future as they had in the past, the engineer designing without giving sufficient thought to the construction problems and the contractor taking risks which he had neither the time nor the information to assess prior to entering into a contract, and later paying the price for his folly.

Mr B. P. Ingamells, who said he approached the Paper from the angle of a user of dry docks and not a constructor, remarked that sheet-piling had been used in the construction of a dry dock in Shanghai in 1929, and he understood it was still functioning satisfactorily. The dock was 400 feet long.

The Author had mentioned the possibility of cathodic protection for sheet-piling, and it would be interesting to know whether anything had been done in that direction since the Paper had been written.

Up and down Britain there were many docks more than 50 years old, and some of them as much as 200 years old. Could the Author give any indication of how long he thought the sheet-piling would last? Mr Ingamells put that question seriously, because if there was local seepage and corrosion the repair of sheet-piling as a wall side should be easy compared with the work required to deal with the acidulated attacks which sometimes took place on concrete walls of the normal design. The problem of renewing some of the walls in docks in Britain in such circumstances could be quite a serious civil engineering problem.

Would the Author explain why the dock floor was so thick, varying from about 12 feet at the entrance to about 8 feet at the head ? $\mathrm{Mr}$ Ingamells understood that in the case of other docks under construction in the same area at the present time the bottom was nothing like so thick.

It was stated in the Paper that the filling of the dock could be carried out in about $1 \frac{1}{2}$ hour, but that there were additional sluices which could be used to accelerate the operation. What was the quickest time in which the dock could be filled?

The overall cost of the project $(£ 1,250,000)$ might seem very large to the Doek Company and their directors, but to Mr Ingamells it seemed very reasonable and indeed astonishingly so compared with some of the fantastic figures which he had been given over the past 18 months for various dock projects in Britain. The Author had already been asked to give a breakdown of the costs, but $\mathrm{Mr}$ Ingamells was particularly interested in the cost of the lift. He knew that at the dock in question there 
were special reasons for the lift, in particular the difference in height between the workshop area and the dock coping, but, having been in the bottom of nearly every dock in Britain, he would recommend all dock owners to install a lift in each one. Mr Ingamells believed that that would pay from a management point of view. He had in mind particularly some of the bigger docks, such as the King George $V$ at Southampton, the new Tilbury Dock, and others which were quite deep. When a squad of men were working in the bottom they should be properly supervised, but the number of steps down to the dock floor acted as a deterrent not only to the managers, but also to the foremen and charge-hands. He felt that the management were influenced in that matter by a tradition, dating from the 200-year-old docks which he had already mentioned-there was one at Bristol and one on the Thames-so that lifts were not expected; for the sake of industrial efficiency, however, there ought to be lifts, at least in modern docks.

Mr G. M. Cornfield asked the Author a number of questions relating mainly to the arch dam and the deep-water quay. In the cross-section through the arch dam shown in Fig. 11 the space between the sheet-piling and the steel walling was shown as filled with concrete. Since that concrete had presumably been placed under water with some difficulty, had there been some special reason for its use in place of the more usual folding timber wedges? Again, the construction of the concrete arch rib at dredged level could not have been a very simple matter. Did the Author consider that that additional rib was in fact essential? If the stiff or hard boulder clay occurred at the dredged level it would appear that the passive resistance of the clay should be quite adequate to support that part of the piling below the lowest steel rib, which was only about 5 feet above the final soil level. Furthermore, for that condition the stress in the sheetpiling would not be high.

The detail of the actual connexion of the end distributing girder of the arch dam to the abutments was not quite clear from the Figures given in the Paper. It looked as though the girder was simply placed against the piling of the abutment without any form of connexion or fastening being used, but was that assumption correct?

The construction of the deep-water quay and its use as a temporary dam were interesting, but it seemed likely that the large deflexions which occurred following dewatering were caused by the use of clay as a filling material near the bottom. The cross-section through that quay given in Fig. 8 showed that additional anchor piling 7 feet long was provided for the final quay wall, but since that anchorage was located in the clay filling, how effective could it be? Had any subsequent forward movement of the quay been observed?

Had any attempts been made after dewatering to reduce the amount of seepage through the interlocks of the arch dam and deep-water-quay 
piling, for example, by the use of ashes or other fine materials placed in the water outside the piling? If such measures had been taken had they had any useful effect? In two recent cases of steel sheet-piling cofferdam construction, one on land and the other in water, the interlocks had been successfully caulked from the inside of the dams using a material called "Philplug," which was made in rope form from asbestos fibre and which was sometimes used to caulk the joints of pipes and tunnel-lining segments. In both cofferdams the seepage through the interlocks had not been excessive and could easily be dealt with by normal pumping. However, the concrete walls had to be constructed in direct contact with the sheetpiling, which was to be permanent, and it was therefore very helpful to be able to stop the seepage completely by means of that caulking.

The Author stated that cathodic protection might be applied to the permanent sheet-piling, but would such protection be effective in the case of the dock-wall piling, which would be immersed only for relatively infrequent periods?

Mr G. A. Wilson remarked that reference had already been made to the cost of the new dock $(£ 1,250,000)$, which included the fitting-out berth. A dry dock of much the same size, constructed at Tilbury about 30 years ago, had cost about $£ 800,000$ without a fitting-out berth. Bearing in mind the enormous increase in costs in that period, the comparison brought out the economic success of the enterprise.

The Paper was a valuable record of the construction of a dry dock, which could be read in conjunction with the "Memorandum on the Construction and Equipment of Dry Docks" published by the Institution. The latter presented the theory whilst the Paper provided the practical application and the points to which he proposed to refer were those which, in his opinion, merited further consideration when the next dry dock was built.

He would first like to mention how simple and satisfactory much of the detailing was, and draw attention to the $1 \frac{1}{8}$-inch-diameter U-bars fitted round the top of alternate piles to secure the sheet-piling.

The dock did not seem to provide for stabilizers fitted to ships, and possibly the design had been made before those came into prominence. It would be difficult to make slots in the side of the dock for the removal of the blades, which had to be done when the ship docked. The blades of the stabilizers now used on the Orient liners were about 20 tons in weight, so that possibly the large dry-dock crane should have had a larger auxiliary hoist, say 20 tons at 135 feet. He would like to know if the cranes used A.C. or D.C. electricity supplies.

With regard to the contractor's dam, would it be too much to ask for a figure of cost for the work between the abutments?

The dock had supplies of electricity, air, steam, and water for connecting to the ship, so that it seemed that the ship could be occupied while it was 
being overhauled. Although it was generally considered to be too difficult, he wondered if the Author had considered connecting the ship to a sewerage system.

There was one detail that had already received some praise which $\mathrm{Mr}$ Wilson considered thoroughly undesirable from a maintenance point of view. It was the cable trench for the crane. Now that it was possible to get robust flat-fitting quay plug-boxes, he thought that a trailing cable was much more convenient and was to be preferred.

Would the Author give the reasons for using centrifugal pumps instead of axial-flow pumps; the latter were frequently employed to move large volumes of water at low head.

A detail which was not usual in the London area was the use of $1 \frac{1}{4}$-inchthick pitch-pine packing under the keel blocks. Had there been any special reason for that?

Mr A. Storrar referred first to the dock piling and said that the Author had mentioned the difficulty in driving the Larssen piles. Those had presented very real problems at the time. On the first length of piling referred to 120 piles had been pitched and driven in the usual manner. Mr Wilson had already described the shape of the piles and the hardness of the driving. It had been found on later examination that very few of those piles could remain without attention in some form or other. It so happened that in that length of 120 piles some of the hardest boulder clay on the site had been encountered, and not only clay spades but paving breakers had been required to break it up. It had been decided at an early stage that piles which were more than about 4 inches out of line at bilge-altar level, either inwards or outwards, had to be removed, whether damaged or not, and the clay behind the piles trimmed where necessary to allow the piles to come back to their proper line. Probably about half the piles were used without much repair. A few were shortened where local damage had occurred to the toes. The remainder required quite extensive repair, if not complete scrapping.

Spliced piles had been arranged so that any splices were, when the pile was pile-driven, below the top of the floor level. Special splice plates, 1 -inch thick (the same as the web of the pile), 24 inches long, and 18 inches in girth, each with two 6-inch-diameter holes in them, were bent to the profile of the pile. The two portions of the pile, in the case of a spliced pile, were laid out on a jig and the ends prepared for welding and buttwelded. The special splice-plates were then clamped in position, tackwelded, and finally welded all round, and around the periphery of the 6-inch hole. The plates also were in pairs_- "insides" and "outsides"and care had been taken when pitching those spliced piles to see that the splice-plate was always on the dock side of the pile, so that when the pile was slid down the groove formed by the pile which had been removed it was not pushed forward in the head. 
In some cases whole panels of piles had to be removed, and then a closure pile was required. Two of those had been riveted up on the site. The driving of the piles in the trenches, the method which had ultimately been adopted, could be classed as completely successful. Boulders were encountered in plenty, but damage serious enough to warrant removal and repair of the piles had been slight, and probably occurred in only about 1 per cent of the piles so driven.

The impermeability of the virgin clay left nothing to be desired in nearly the whole length of the dock. Practically no water was encountered during construction, and very little seepage had occurred since. When the boulder clay was used as filling, however, it could not be classed as impermeable, and on the south-east wall, where the piles were backed by that clay filling, the design assumption that the filling was waterlogged to high water mark was probably correct. Considerable leakage occurred when the two drains leading to the sump (mentioned on p. 379 of the Paper) were closed and the water allowed to rise in the filled material. It had then been decided to release the water pressure by opening the valves, drain off the filling, and weld up the clutches of the piles before finally closing the valves. That had been done on about 150 piles and the leakage had been reduced to a negligible amount.

With regard to the concrete sills and quoins, the quality of the concrete of which those precast blocks were made was first class and the initial dressing, done in the contractor's yard, produced excellent results. It had been noticeable that, when those sills and quoins had been carefully set, there had been very little dressing to be done. When the accuracy on the 6-foot steel straight-edge was exceeded a 10-foot straight-edge was used and only a very small gap at any place had been found using the latter.

No further adjustments had been required after stepping the gate. The leakage had really been non-existent. A contributory cause of that was the rubber seal on the outside of the greenheart facing on the gate. The benefit of that seal had been adequately proved by the fact that after one particular docking a 10-gallon paint drum had been caught between the greenheart and the stone, and completely flattened. No leakage had occurred and what had happened had only been discovered because the gate-locking gear had been rather more difficult to shoot home. No damage had occurred to the greenheart or to the concrete after that episode.

Mr Holloway had mentioned some of the benefits of the arch dam, but one which he had not referred to was that it had allowed the dock gate to be built on a solid concrete foundation inside the dock and to be stepped in position with a constant water level, so that there were no worries about stepping the gate on a rising or a falling tide. The arch dam, as $\mathbf{M r}$ Wilson had said, was a sound engineering structure, but Mr Storrar considered that it was a vulnerable structure, because, owing to the angle to the river at which the dock was sited, any ship which was out of control 
in the river could have damaged it. However, the contractor's luck held and no damage had been done during the period that the arch dam was in use.

Mr F. J. Watkins said that his Company was one of the unsuccessful tenderers for the work and that they had considered the use of both the arch and gravity dam, but at that time they were constructing the new dock at Sunderland and had spent many anxious nights wondering if a ship would hit the dam so they had decided on the gravity dam. Furthermore, they had found at Sunderland that working in bad ground with a single-skin dam they had several blows, but with the gravity dam they had no trouble from that source.

Mr Watkins felt that if a gravity dam had been used at Smith's dock there would not have been the trouble with the pump-house. When preparing the tender it was thought that the gravity dam could have been constructed at an earlier stage and that would have offset any saving in time due to the easier removal of the arch dam.

The difference in cost between the two dams would be small compared with the varying estimates of the number of steel piles that could be driven in a day.

Mr Watkins wondered if consideration had been given to excavating down in bulk excavation before pitching the piles, a procedure which was being followed in the construction of a dry dock on the opposite side of the river when similar ground was encountered.

Mr J. H. Jellett asked for further information about the calculations for resisting hydrostatic pressure. It was stated on p. 360 of the Paper that that was taken by the sheet-piling. Below the floor that sheet-piling appeared to have only about 6 feet of penetration. It was exposed over most of its length, and as kentledge at the top it had only the concrete structure containing the subway. Obviously the problem had been satisfactorily solved, since the dock had not floated, but it would be interesting to know the assumptions which had been made and the figures which had been taken in arriving at the conclusion that the piling would be sufficient to take the uplift.

Mention was made earlier in the Paper of the subject of maintenance. Clearly the face of the sheet-piling could easily be maintained. Nevertheless, labour costs were now so high that the necessity for such continual maintenance throughout the life of the dry dock was not desirable. Recently there had been one or two rather alarming examples of preferential corrosion in sheet-piling, where the buried portion of the pile functioned as a sacrificial anode to the exposed portion. It would certainly be advisable to consider, as indeed the Author had suggested, whether a full scheme of cathodic protection should not be provided.

It was certainly in the interests of all dry-dock projects to reduce the amount of excavation involved in their construction, because for some 
extraordinary reason only a portion of that excavation was allowed as a capital cost of the dock for depreciation allowance. Mr Jellett had never been able to understand the logic of such a distinction. It appeared that the structure of the dock was treated as a wasting asset, and so the excavation necessary to put that structure in was similarly treated, but the open space, the working area of the dock, which it was the aim to create, was for some reason not treated in that way and therefore not allowed for depreciation purposes. He hoped that one day that extraordinary anomaly in the system of taxation would be remedied.

Mr Jellet gave a word of warning on the subject of the stepping and unstepping of Box gates-a subject on which he had spoken previously with reference to his experiences at Dover. The conditions of user at Dover and on the Tyne were not quite the same, but on p. 381 of the Paper it was stated, on the basis of the stepping carried out, that " the facility with which gates of this type can be handled is a great advantage from a maintenance aspect." To step the gate behind the shelter of a cofferdam, with the water level under control, was one thing, but to step it in the tideway, which was presumably the way in which it would have to be done next time, was going to be entirely different. However, that would probably not arise for another 15 years.

It was interesting to note that hand-rails or safety railing had been provided all round the edge of the dock. So far as he was aware that was not yet statutory, but the new Shipbuilding and Ship Repair Regulations, which were to be introduced under the Factories Act and which were now in draft, would attempt to make it so. Dry-dock owners at Southampton, in conjunction with others throughout Britain, were naturally strenuously resisting the idea of it being made compulsory. Their argument was that such railings had to be removed for the operation of the dock, for bringing ships in and so on, and if as so often happened they were not replaced, and an accident took place because someone thought that the railings were there when they were not, endless argument would ensue.

Mr Jellett said they had recently been engaged in litigation arising out of an accident in which a dock worker at Southampton had fallen into one of the docks. The man had not survived the accident and his relatives had brought an action against the dock owners. It was interesting to note that the judge had not said that because it was a dry dock it ought to have been fenced off, and there was in fact no legislation to that effect but he had quoted the section of the Factories Act which provided for the fencing of an opening in a factory floor, and he had then defined a dry dock as being an opening in a factory floor, or equivalent to it. Fortunately for the owners of the dock the Court of Appeal had reversed that rather remarkable decision, which went to show that the fencing of dry docks was not yet per se statutory. It was a little disappointing to find that the case which they were now fighting with such vigour had been in part destroyed. 
Mr Ingamells had referred to the subject of lifts and had mentioned the King George V Dock at Southampton. A scheme had been prepared to install a lift in that dock, using one of the now more or less disused timberslide tunnels into which could be inserted a lift similar to the cliff lifts at Bournemouth, and working on the same principle. So far, however, authority had not been obtained to proceed with that work, one of the objections to it being the running cost. The general opinion of all those involved on the operating side was that such a lift would require to have an attendant. It would be interesting to know, therefore, whether Smith's Dock Company had found it necessary to provide an attendant for their lift.

Mr Wilson had remarked that it was generally thought to be difficult to provide a sewerage system in the bottom of a graving dock. That had been done in the King George V Dock, and it was now possible to connect up the sanitary outlets of any ship which came into the dock to that system. In addition, suites of portable toilets had been provided which could be lowered to the bottom of the dock and coupled up for the use of the workmen.

Mr J. A. Williams referred first to the clay slopes and asked the Author why he had selected the particular slope chosen and whether he had taken any special precautions to drain the clay. The point of the question was that at the time that the Author had started work on No. 8 Dry Dock Mr Williams had been concerned with a scheme immediately opposite, on the other side of the river, and there they had had the same problem of a clay slope coming down to a dry dock, and they had allowed for a comprehensive system of surface drains. In the same connexion, the Author was probably aware that higher up the river one of the yards had during the past 10 years spent a considerable sum in stabilizing a similar clay slope.

Mr Williams asked whether there had so far been any sign of differential settlement in the concrete anchor wall which tied the main piling. From the cross-section, that wall seemed to call for vertical piling underneath. He would have been inclined to have used some piles, not so much to carry the weight as to avoid differential settlement between the anchor and dock walls, which seemed quite probable because of the heavy crane loading.

Referring to the siphons of the pumping system Mr Williams suggested that better hydraulic conditions might have been obtained by inclining the outlet leg of the siphon inwards. That was reputed to be true for siphons which had to be self-priming; otherwise the problem did not, perhaps, arise.

What method of analysis had been used to estimate the stress in the piling of the quay? The anchor wall at the back seemed rather flimsy in comparison with the rest of the structure. He would have used girders instead of pairs of tie-rods to connect the two lines of piling, and tried to get some form of gravity action with the two skins of piling, so as to obviate 
the necessity for the rather light anchor wall. When the quay acted as a cofferdam there had of course been no anchor wall, and the load conditions in the permanent state were probably less severe.

$\mathrm{Mr}$ Williams considered that it was possible on the north-east coast to produce good concrete over long periods with variable aggregates. The point was that it was necessary to pay for it by more cement or otherwise. He thought that the answer was to make it clear at the tendering stage that a certain quality of concrete was required, and then, if the contractors appreciated what was wanted and that it would be paid for, it gave them a chance to put in a fair price, and one would then get the concrete one specified.

Mr Williams said he had made a rough calculation of the cost of the dock on a cubic foot of dock-volume basis, and, making appropriate deductions for overburden excavation, cranes and so on, he estimated that the cost of the dock from coping level, including pumps and gate, was about

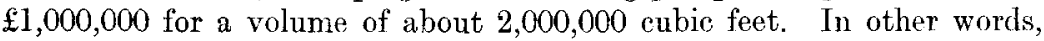
the cost per cubic foot was slightly less than $10 s$. By comparison with other dry docks with which he had been concernel recently, that compared very favourably.

It had been stated that this was the age of the common man. Personally, he believed that the reverse was true. Great opportunity was given in this age to the uncommon man ; and, so far as dry docks were concerned, the Author had proved himself to be an uncommon man, and Mr Williams had found his work inspiring.

Mr H. R. Boyce, confining his remarks to the fitting-out berth, asked whether its design had ever been considered purely from the point of view of cellular cofferdams, making use of straight-web piling. He was aware that straight-web piling was not rolled in Britain, except possibly for the old Universal or side-grove piling, which required a pile with independent clutches. It might be that the Author had considered that the driving likely to be encountered would be too hard for a piling which had a small sectional modulus. The other point which arose was whether or not damage occurred to the Larssen piling Nos 5 and 3 which were used for the fitting-out berth. Possibly one objection to using cellular cofferdams with straight-web piling was the class of fill available and there again he would appreciate any information which the Author could give.

** Mr E. L. Champness said that to the users and owners of dry docks the details given in the Paper would be of great value.

Even before the construction of the dock under discussion Smith's Dock Co. Ltd had already taken steps to fulfil a want which was increasingly overtaking the business of ship maintenance. In the broad interests of

** This contribution was submitted in writing upon the closure of the oral discussion,-SEC. 
Britain's supremacy in that matter, both from naval and mercantile considerations, such enterprise should be welcomed.

For many years dry-dock construction had not kept pace with development in ship design, but the wounds arising from the depression in the industry in 1929-33 were deep and had only just healed.

Subsequent events had proved that postponement of new dry-dock construction had meant a higher cost eventually, so that those first in the field had reaped the benefit.

Mr Champness said that he would have amended the design of the dock as followed :-

(1) Increased the breadth by about 10 feet.

(2) Introduced a crane shunt to enable aircraft-carriers to dock and their flight-deck and sponson projections to clear the dockside cranes.

Mr Champness was aware that that was mainly a naval consideration but other factors, such as space required for overhaul and fitting of antirolling devices, required width of dock apart from developments in beam which might take place in the next 50 years.

He noted that the usual side drainage channels which served to remove sludge and mud, etc., had been omitted. Those were, as mentioned in the Paper, always full of dirt and refuse but that had to be got rid of. The usual methods of clearance by hand labour were expensive nowadays. He favoured the use of large sumps lined with steel skips into which the mud and refuse could flow or be swept and which could periodically be removed in bulk by the dock-side cranes.

The Author, in reply, said he had expected rather more criticism of what was a rather unconventional design.

Many of the speakers had been concerned with cost, which had been mentioned several times. He could not give very full particulars, but he could say that the cost of the civil engineering work in the dock and the deep-water quay was $£ 802,000$. That was quite apart from plant and various subsidiary structures and buildings which had been provided, the cost of which was of the order of $£ 240,000$. In those costs about $£ 136,000$ had been due to variation of price of labour and materials, which, it would be appreciated, was a very substantial proportion of the total cost. Nevertheless, there was no doubt that the dock, even after paying for the difficulties which had been encountered, was a much cheaper job than any form of gravity-wall dock of the same dimensions.

$\mathrm{He}$ had been asked if he would adopt the same design again. His answer was that in a case where the ground conditions were known beforehand to be the same, he would not; but that did not mean that he would use a gravity wall. The construction of every dock had to be considered primarily from the point of view of the ground characteristics and the site 
under discussion had seemed suitable for the methods adopted. Appearances had later proved to be deceptive, but even so the design adopted had been cheaper than the conventional design.

With regard to the merits of the arch dam and of the double-skin gravity cofferdam, there was a good deal to be said on both sides. The arch dam was a very good one, but it had to be built with considerable care. It was vulnerable to damage from shipping, but was quite watertight. At the tender stage the engineers had suggested on the contract drawings a double-skin cofferdam, gravity filled, such as Mr Watkins had mentioned, and the Author still felt that some of the difficulties might have been overcome had such a dam been used, but it was exceedingly difficult to make a definite statement on the matter at that stage.

It was known that failure to find boulders by borings was no guarantee that boulders did not exist, so, as stated in the Paper, provision had been made in the contract for dealing with them. However, the large number actually found had been surprising.

Mr Ingamells had referred to the use of sheet-piling in a dock at Shanghai in 1929, which was very interesting; it was quite unknown to the Author and he would welcome details.

With regard to cathodic protection, the Author did not feel that that had reached a stage at which it was possible to make a decision one way or the other. Various experiments were proceeding on the Tyne and elsewhere. For the time being he was waiting to see whether such methods were effective. It did not appear to be a cheap method of protecting piling.

The probable life of the dock was an extremely difficult question to answer. It was obvious that the inside of the dock could be well protected, and other piling driven within a few hundred yards had not corroded on the back face at all, even when immersed in water. He had no fears about the life of the dock as a whole, provided it was properly maintained, and he was sure that Smith's Dock Company would maintain it properly.

With regard to the possibility of forward movement of the anchorage or the piling, he could say definitely that there had been no visible movement at all since the completion of the work. A sight of the ground would have convinced Mr Williams that piling was quite unnecessary under the anchorage.

The use of stabilizers on ships might present some difficulty, but their employment seemed to be exceptional and unlikely in tankers, for which that dock was designed.

The cost of the civil engineering work had been given as $£ 802,000$ for the dock and deep-water-quay extension of 380 feet. It was impracticable to separate clearly the costs of those two structures since one gained support from the other; the excavation from the dock was used as filling to the quay and the cofferdam was common to both. It could be stated, however, that the approximate cost of the dock alone was less than $£ 1,000$ per linear foot. 
In reply to Mr Loewy's point as to why borings were not put down on the line of the walls instead of on the centre-line, the Author considered that in ground of that type it was a matter of chance whether the borings hit the boulders or not. In that case chance had not divulged the truth.

It was quite true that boulders were disclosed during the digging of the overburden but at that stage it had been necessary to order the sheet-piling since the rolling mills would only provide the thicker section on the understanding that the order was placed so that one rolling only would be necessary. In fact, some piles had been delivered so a departure from the design was not practicable at that stage.

Mr Storey Wilson had stated that the piles could not be driven into the boulder clay, but that was not strictly correct. Where there were no boulders and where adjacent piles were unaffected by boulders, it was possible to drive the sheet-piles 40 feet into the clay-the whole trouble was the large numbers of whinstone boulders encountered, as explained in the Paper.

Mr Loewy's suggestion of sinking boreholes at 2-foot centres was certainly a practicable one and it would have reduced the frictional resistance of the clay and broken up some of the boulders, but unless the holes were placed "cheek by jowl" it would not be possible to remove every boulder (which had been achieved by the trenching method) and the cost of such methods would obviously be high.

Although the sheet-piling was driven after the subway had been built there were no signs of disturbance to the subway.

Mr Watkins had asked whether consideration had been given to carrying out the bulk excavation before the sheet-piles were pitched. It was thought that that would be risky in view of the high embankments surrounding the dock and that it was most desirable to anchor the sheeters before removing the dumpling.

The conditions on the other side of the Tyne referred to by Mr Watkins were not quite comparable; the design was different and possibly they had benefited by experience on No. 8 dry dock.

Mr Storey Wilson's comments were rather reminiscent of " being wise after the event." The fact that the three borings put down in the.river showed tidal variations was, in the Author's opinion, not convincing proof that there was water under hydrostatic pressure throughout the strata encountered.

In the Author's experience it was most difficult to get borings taken in water without it penetrating down the outside of the tube and up the inside, thereby giving the impression of tidal water in the strata itself, which was naturally extremely misleading. He, therefore, was not unduly worried at the results of those three borings and it had appeared in the construction work as if there was no general hydrostatic pressure, although there were obviously passages in the sandy strata which might have been the cause of the blows. It was considered that had the contractor not excavated a 
sump close against the sheet-piling on the river side of the pump-house to within a distance of 3 feet or thereabouts of the toe of the piling, it was quite conceivable that a blow in the pump-house might never have occurred.

Mr Storey Wilson's suggestion that compressed air should have been used on the pump-house and other parts of the job was rather interesting. In tenders for a similar dock contract which the Author's firm issued about 12 months ago provision had been made for constructing the pump-house under compressed air. It should be mentioned that the ground at that particular site consisted of water-bearing silts and sands with some known obstructions; hence the reason for suggesting compressed air. However, the tenderers, without exception, all indicated that they would prefer to do that work in cofferdam. The use of compressed air would have made the work enormously more expensive.

It had been asked why a single line of piling was not used for the quay. It was considered necessary to execute the dock construction in the dry and whilst the arch cofferdam provided the protection at the entrance a length of about 220 feet of dock wall on the south-east side was not protected. It would have been feasible to construct a cofferdam along that length but it was considered more advantageous to use a slightly longer dam in the form of the deep-water quay and make use of it as a permanent strueture, with the great advantage of using clay filling in the dry.

Mr Boyce had asked whether straight-web piling was considered for the deep-water quay. The answer was in the affirmative, but it was decider that it would most probably be too light for driving into the stiff clay and, further, it was not available in Britain.

The filling valve had been used on the North-East Coast in several docks but the Author was not aware whether it had been employed elsewhere in Great Britain. That type of valve was to be used in Holland for docks larger than the one described in the Paper, for both filling and in lieu of a sluice valve where two docks drained into the same sump.

The cost of the valve was about $£ 1,800$ and no electrical work was required.

Mr Ingamells asked what would be the quickest time in which the dock could be filled, using both the filling valve and the sluices in the gate. That was assessed at slightly more than one hour.

The desirability of increasing the crane capacity, as mentioned by Mr G. A. Wilson, was seriously considered and it was felt that the provisions had gone as far as was economically justifiable. The cranes used alternating current, as stated in Appendix II.

Mr G. A. Wilson's criticism of the use of a collector trench for the electrical pick-up for the cranes was not supported by Smith's Dock Co. They strongly believed in the trench system as compared with the trailing cable. That was a contentious point but general opinion in ship repair yards seemed to favour the trench because maintenance costs were high 
for trailing cables since they were very susceptible to damage from plates, bolts, and such like.

The crane collector trench had been found to be quite satisfactory in operation. So far as was known no bolts, etc., had fallen in but even if they had they were unlikely to cause any trouble since they would have fallen clear of the wire conductors. Hand access to that trench was obtained at 20 -foot centres where the insulators were located as described in the Paper and it was considered that the copper conductor wires could be readily manipulated between those points.

It had been suggested at one time that snow might be a source of trouble inasmuch as it might become packed tight by the pick-up arm. That had not occurred and even if snow did accumulate it would be an easy matter to clear it by means of a steam jet.

Criticism had been levelled at the thickness of the dock floor and suggestions made that it might have been thinner. The Author's opinion was that if the thinner floor had been adopted it would obviously have been necessary to vent the floor so as to prevent the development of hydrostatic pressure. That matter had been carefully considered and it was felt that a water passage between the valves would undoubtedly have softened the clay which would have choked the relief valves in time, probably resulting in serious trouble.

It was not thought that that strata was suitable for a vented floor and under those circumstances it was obviously essential to design the floor against a possible hydrostatic head. The pressure from that head was counteracted by the dead weight of the floor, the wall piling, and the subway; the balance was taken by frictional resistance on the piling below the top of the floor. That resistance did not exceed $3 \mathrm{cwt}$ per square foot of piling surface. Generally the penetration of piling below the floor surface was about 17 feet.

Mr Ingamells had suggested that the dock floor was thick compared with others under construction. The Author knew of only one other modern dock with a thin floor, except where the sub-strata was rock, and he had personal knowledge that the larger new dry docks now being built on the Continent all had thick floors up to as much as 26 feet thick in one instance.

No ship-to-shore sewage system was embodied since it was considered that those facilities would be reasonably provided for by means of the lavatories which were specially built on the dockside for ship personnel.

Tenders were received for axial-flow pumps as well as for centrifugal pumps and the latter were less costly. In the opinion of dock owners they were more reliable and readily maintained. It was true that axial-flow pumps occupied less space in the pump-house but the slightly reduced civil engineering work did not compensate for their higher initial cost.

It was customary on the North-East Coast to provide a soft-wood packing under the keel blocks and there was no difficulty and relatively small expense in replacing those from time to time. It served the invaluable 
purpose of "taking up " irregularities in the concrete floor and preventing fractures of the cast-iron blocks.

It was agreed that the provision of hand-rails around dry docks was not compulsory at the present time but there seemed little doubt that that would come before very long. It was, therefore, felt desirable to embody them in the scheme initially. The Author knew of at least one other dock where hand-rails of a removable type had been fitted for more than 30 years and apart from the one or two rails around the bollards they had never been removed and, therefore, hand-rails could not be considered a serious handicap to the docking facilities and were a very definite safeguard against accidents.

No lift attendant was provided but the control of the lift at docking times was placed in the hands of the foreman electrician who was responsible for putting into effect all the safety devices which prevented the lift travelling below coping level while the dock was flooded.

The taxation angle which Mr Jellett outlined was one which was very much in the minds of dock owners and it was certainly an anomalous position. It was to be hoped that the revenue authorities would take a more realistic view of the taxation reliefs on dry docks in the near future.

Mr Champness's comments concerning the amendments he would have made to the design were interesting, but the dock dimensions had been the subject of much detailed consideration by Smith's Dock Co. and, as stated in the Paper, the dock was primarily intended for tankers and not aircraft carriers.

The omission of side drainage channels was justified in the Author's opinion, since they were never self cleansing and it was more difficult to clean channels than squeegee the floor. It was quite feasible to remove the mud and sludge, etc., from the dock sump through the vent shaft by skips handled by the dockside cranes.

Mr Williams asked whether any drainage was provided for the clay slopes. The answer to that was that no special provisions were made but during construction work much of those slopes was left ungrassed and drainage runnels were formed here and there but no slips were caused as only the face of the clay was softened, which enabled the slopes to be grassed, generally by strip turfing and seeding.

The stress analysis on the permanent condition of the deep-water quay could be considered to give only a rough approximation of the forces from the filling, particularly in view of the varied character of the material and of the varying water levels. It was, however, considered that the inner line of steel piling would provide the necessary passive resistance to overcome the active forces on the outer skin. In view of the fact that the anchorage was rather near the active zone it was considered desirable to supplement that anchorage by another one from 30 feet distant.

There was little doubt that the temporary conditions on that structure when functioning as a cofferdam were more onerous than the final conditions 
and observations were made to ascertain whether any movements occurred as the filling was brought up, but none were observed.

The quality of concrete aggregates on the North-East Coast was generally poor but it was possible to obtain whinstone aggregate at a quite appreciable increased cost. Except for special circumstances it was considered unjustifiable to use it.

The principal trouble with the local aggregate was that it was not properly washed but if the suppliers could be persuaded to wash it thoroughly it made a tolerably good concrete. Unfortunately, there was such a demand for aggregate in that area that the suppliers were not too inclined to meet one's wishes in that respect, and it was largely a matter of perseverance until the requirements were achieved.

The subject of corrosive action on sheet-piling was one about which there was obviously very much to learn. It appeared from present information that the rate of corrosion in sea water was about 3-4 thousandths of an inch per year and if that rate applied to the dock piling, then the effective life would appear to be at least 60 to 80 years and by then the dock would probably be out of date.

At present cathodic protection was being much commercialized and had a wave of popularity but were its fundamental basic principles sound ? The Author considered that it would do no harm to leave the piling for 5 years or so, by which time more light might be thrown upon the efficiency or otherwise of cathodic treatment.

$\mathrm{Mr}$ Ingamells rightly mentioned the deterioration which took place in concrete dock walls. Many docks of 60 years of age or more did not present a very satisfactory picture and it was to be hoped that those now being built in reinforced concrete would show up better 60 years hence. The problem of repairs to those old structures was a most difficult one; in many cases it would be more satisfactory to demolish them and rebuild, but it was difficult to make dock owners see it in that way.

$\mathrm{Mr}$ Storey Wilson had claimed that the arch dam was cheaper than a gravity filled dam and that the latter would have taken several months to remove.

From experience of recent contracts there appeared to be little difference in the costs of the two types of structure. The arch dam demanded a much greater degree of accuracy in its construction and that of the permanent abutments, consequently it was slower. Although there was a smaller tonnage of material the rate per ton of the prefabricated material in ribs, etc., was obviously much higher.

The placing of the vertical distribution girders and the arch ribs were all tidal operations and needed careful supervision. Another pre-requisite for that type of dam was the provision of adequate permanent structures which could be employed as abutments.

On the other hand the double-skin gravity cofferdam could be a much rougher structure, although more piling was required. It could be built 
independently of the permanent works which was frequently a great advantage and having a double skin it was less susceptible to "blows."

The operation of filling and removing the ballast was not a big one if a ballast pump was used. The removal of a dam of that type was not such a long operation as Mr Storey Wilson suggested.

The great weakness of the arch dam was its susceptibility to damage from the blows of ships with the probable consequent serious interruptions to the construction work ; fortunately that did not happen in the present case.

The idea of filling the "pans" of the piles with concrete at the various ribs was presumably to provide a good bearing for the piles. Since the piles were driven tight against the frames, using them as guides, it was not

Fig. 22.-Bearing for ARCH-DAM FRAME

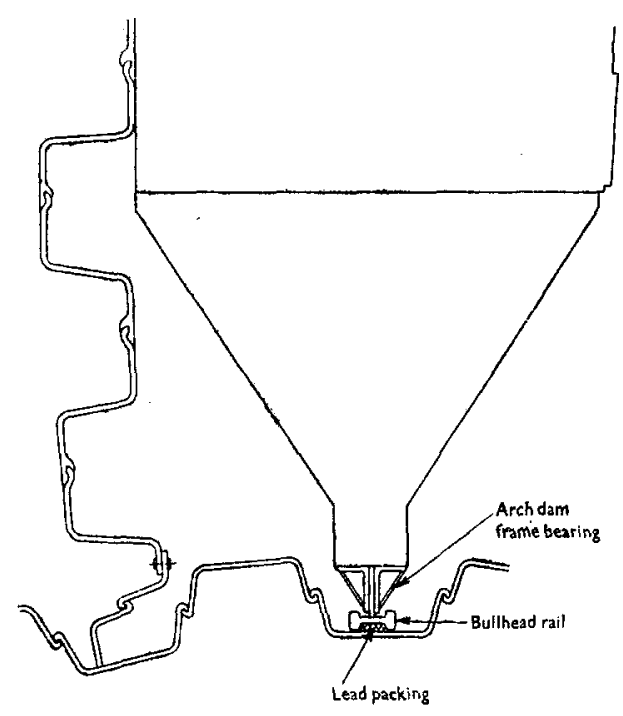

possible to use timber packs. The concrete rib which was placed at riverbed level was a contractor's afterthought and the engineers did not consider it essential.

The vertical distributing girders at the abutments were set in a bullheaded rail which was fixed truly plumb against the permanent piles: the space between the web of the rail and pile was run with lead (see Fig. 22) to provide a uniform bearing.

To cater for a possible reverse pressure during construction a wire rope 4 inches in circumference was strained on the outside between a bollard on the east roundhead and a substantial cleat welded to the west roundhead at a level of about $+9 \cdot 0$ O.D.

The closing date for Correspondence on the foregoing Paper was the 1st April and no contributions other than those already received at the Institution will now be accepted.-SEC. 